\title{
A Distribution Line Model for Lightning Overvoltage Studies
}

\author{
Susumu Matsuura Member (CRIEPI, s-matsu@criepi.denken.or.jp) \\ Taku Noda Member (CRIEPI, takunoda@criepi.denken.or.jp)
}

Akira Asakawa Member (CRIEPI, asa@criepi.denken.or.jp)

Shigeru Yokoyama Senior Member（CRIEPI, yokoyama@criepi.denken.or.jp)

Keywords: distribution lines, direct lightning stroke, lightning overvoltage, EMTP, modeling

\section{Abstract}

The authors have previously clarified the surge response of a distribution line by pulse tests using a reduced-scale distribution line model (Fig. 1). In this paper, first, the results of the pulse tests are simulated in the EMTP using a conventional model which represents a distribution pole by a single lossless distributed- parameter line model, and comparisons with the test results show that transient overvoltages generated at the insulators cannot accurately be reproduced by the conventional model. This indicates that a special treatment is required to represent the transient response of a distribution pole and wires. Then, this paper proposes new EMTP models of the pole and wires which can reproduce the transient overvoltages at the insulators.

\section{Main Results}

This paper proposes two EMTP models, one for without a ground wire and the other for with a ground wire. The parameter values of the proposed models can be determined based on a pulse test result. Figure 2 shows the latter proposed model. The following components are included in the model: (1) $C_{p}$ and $C_{g}$ : capacitances that simulate the time response of the voltage rises of the pole and the ground wire, (2) $R_{p}$ and $L_{p}: R L$ parallel circuit that represents an initial high value of the footing impedance, (3) $e_{1}, e_{2}$, and $e_{3}$ : controlled voltage sources that represent the time variation of coupling between the ground wire and the phase wires.

The calculated insulator voltages obtained using the proposed models are compared with the measured ones (Fig. 3). It is clear that the calculated results reasonably agree with the measured results.

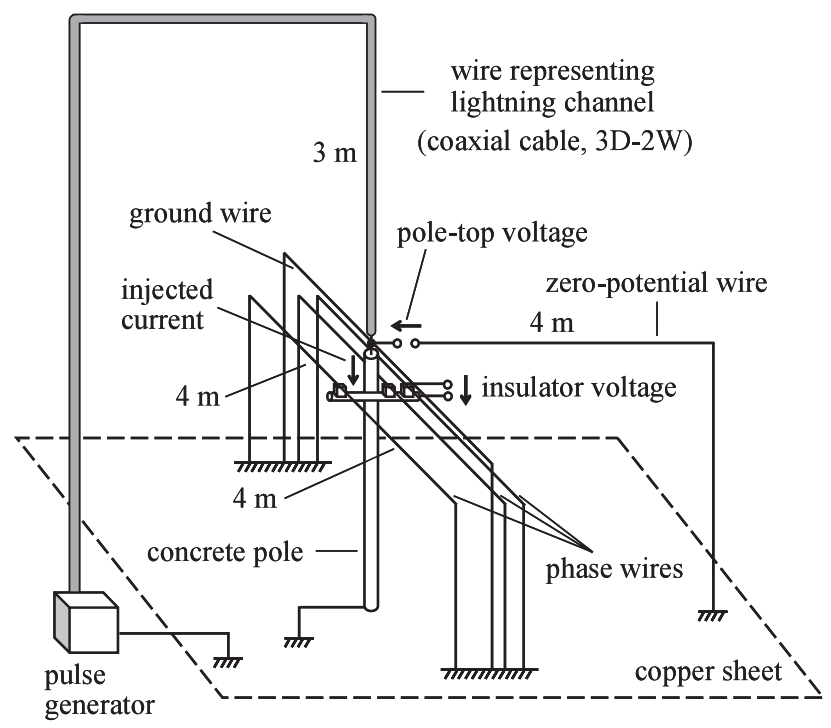

Fig. 1. Experimental setup

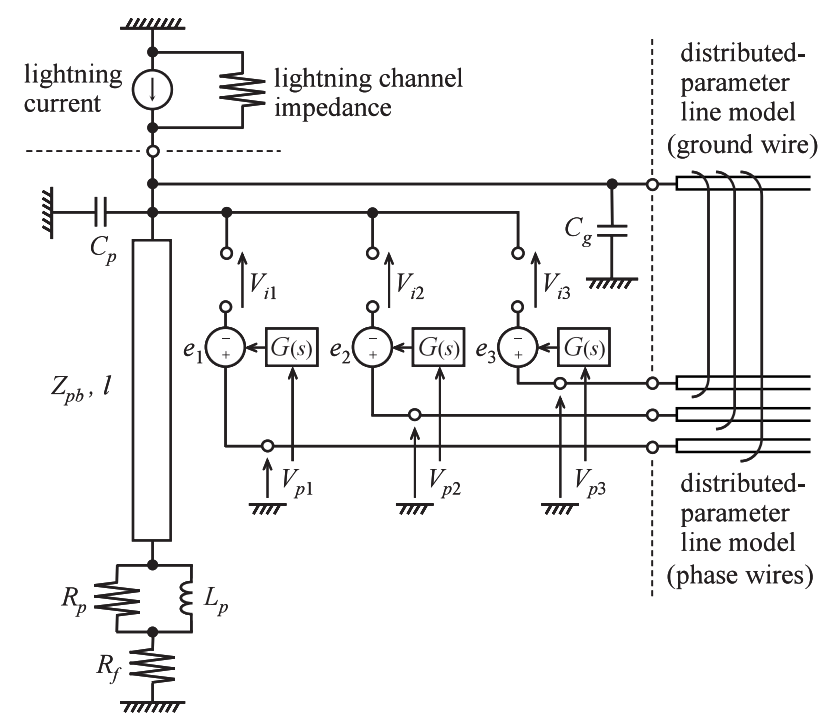

Fig. 2. Proposed EMTP model of a distribution line

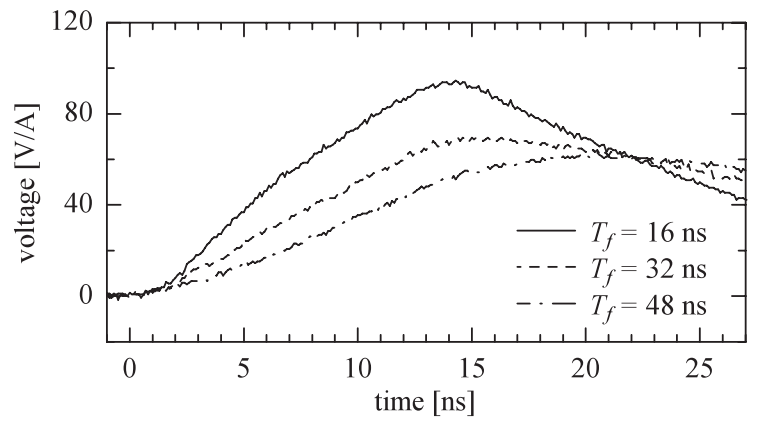

(a) Measured results

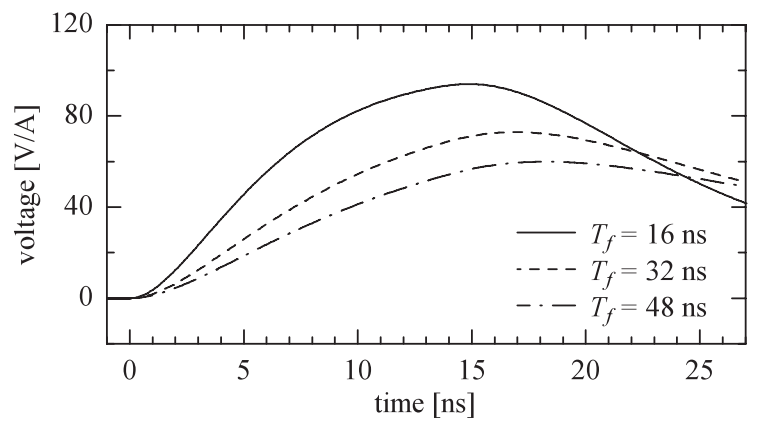

(c) Calculated results

Fig. 3. Comparison between measured insulator voltages and calculated ones obtained by the proposed model 


\title{
雷サージ解析のための配電線モデル
}

\author{
正員松浦 進* 正 員 野田 㻟* \\ 正 員 浅川 聡* 上級会員 横山 茂*
}

\section{A Distribution Line Model for Lightning Overvoltage Studies}

Susumu Matsuura*, Member, Taku Noda*, Member, Akira Asakawa*, Member, Shigeru Yokoyama*, Senior Member

Recently, the focus of lightning protection measures for distribution lines has moved from a nearby lightning stroke to a direct lightning stroke. Studies of direct lightning stroke countermeasures are generally carried out by digital simulations using the EMTP (Electro-Magnetic Transients Program). Thus, components of a distribution line must be modeled appropriately in the EMTP for accurate simulations.

The authors have previously clarified the surge response of a distribution line by pulse tests using a reduced-scale distribution line model. In this paper, first, the results of the pulse tests are simulated in the EMTP using a conventional model which represents a distribution pole by a single lossless distributed-parameter line model, and comparisons with the test results show that transient overvoltages generated at the insulators cannot accurately be reproduced by the conventional model. This indicates that a special treatment is required to represent the transient response of a distribution pole and wires. Then, this paper proposes new EMTP models of the pole and wires which can reproduce the transient overvoltages at the insulators. The parameter values of the proposed models can be determined based on a pulse test result.

キーワード : 配電線, 直撃雷, 雷過電圧, EMTP, モデル化

Keywords: distribution lines, direct lightning stroke, lightning overvoltage, EMTP, modeling

\section{1. はじめに}

$6.6 \mathrm{kV}$ 高圧架空配電線（以下，単に「配電線」と記す）に おける雷事故の原因は，主に誘導雷と直撃雷に大別される。 誘導雷については古くから様々な検討(1)(2) がなされ, その耐 雷対策は一通り完成されたといえる。近年，配電線の耐雷 対策の対象は直撃雷に移行してきており，EMTP（ElectroMagnetic Transients Program) を用いた雷サージ解析によ り, 架空地線や避雷器の耐雷効果に関する検討(3)(4), 避雷器 の焼損に関する検討 ${ }^{(5)(6)}$, 避雷器の接地合理化に関する検 討 (7)(8) 等が行われている。

配電線の直撃雷に関するこれまでの研究 (3) - (8) では, 波頭 長が数 $\mu \mathrm{s}$ の緩やかな雷電流に対する検討が主であり，急峻 な雷電流に対する検討はなされていなかった。実際の雷電 流波頭部の波形には，前半は緩やかに立ち上がり後半は急 峻に立ち上がるものが多く観測されており ${ }^{(9)}$, 直撃雷によ り峻度の大きな雷電流が配電線に流入する場合が想定され

\footnotetext{
* (財) 電力中央研究所電力技術研究所

干 240-0196 横須賀市長坂 2-6-1

Electric Power Engineering Research Lab., CRIEPI

2-6-1, Nagasaka, Yokosuka 240-0196
}

る。急峻な雷電流が配電線に流入した場合，雷電流が電柱 を往復伝搬する $0.1 \mu \mathrm{s}$ 程度の短い時間領域において電柱の 過渡応答による過電圧が発生し, 停電を招くスパークオー バを生じる可能性が高くなる。より効果的な耐雷設計を確 立していくためには，この短時間領域も含めて配電線の雷 過電圧を正確に算定する必要がある。しかしながら，この 短時間領域では, 雷電流により生じる電柱近傍の電磁界が いまだ形成の過程にあることから, 配電線の過渡応答（す なわち, 電柱近傍の電磁界形成に伴って電柱頂部の電位が 上昇していく現象等）を電気回路論にて正確に取り扱うこ とができない。これまでの EMTP 解析で使用されてきた 配電線モデル(4)（以下，「従来モデル」と記す）では, 高圧 電線, 架空地線および電柱を分布定数線路にて模擬してお り，短時間領域の現象を考慮に入れていなかった。短時間 領域の現象を正確に再現するには, マクスウェル方程式を 直接数值的に解く数值電磁界解析手法の適用が有効な手段

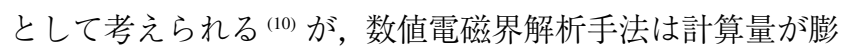
大になるという問題点がある。このため, 雷事故率計算の ように多数回の繰り返し計算を行う場合には, 数值電磁界 解析手法ではなく, EMTP を用いた電気回路論に基づく解 析のように計算時間の短い手法が求められている。本来電 
気回路論では説明できない電磁界形成に伴う配電線の過渡 応答を等価回路を用いて模擬することにより，短時間領域 における配電線の雷過電圧を電気回路論の枠内で算定する

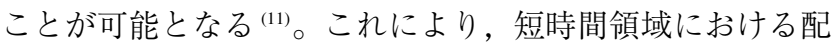
電線の過渡応答を沉用的な解析ツールである EMTPに組み 込むことができ，耐雷設計上最も重要となる高圧電線と高 圧腕金の間に発生する電圧（以下，「碍子間電圧」と記す) を EMTP 解析にて算定できることの実用上のメリットは大 きい。

筆者らは文献(12)において，配電線の縮小モデルを用い たサージ実験 (以下，「縮小モデル実験」と記す）を行い, 短時 間領域における配電線のサージ特性を定量的に明らかとし た。本論文では，先ず，縮小モデル実験の測定結果と従来モ デルを用いた EMTP 解析による計算結果の比較を行い, 従 来モデルの課題を整理する。次に, 従来モデルの課題を踏ま え，短時間領域においても実用的に十分な精度が得られる新 たな配電線 EMTP 解析モデルを提案する。尚, 本論文では, DCG 版 EMTP の最新版である EMTP-RV/EMTPWorks ${ }^{(13)}$ を解析ツールとして使用している。

\section{2. 短時間領域における配電線のサージ特性と従来 モデルの課題}

〈2・1〉 縮小モデル実験の概要ここでは，筆者らが実 施した縮小モデル実験 ${ }^{(12)}$ の概要を述べる。実験回路の配置 を Fig. 1 に示す。大地面を模擬した銅板上に, 縮尺 6.3 分の 1 の配電線の縮小モデルを製作した。我が国における電柱 の主流である鉄筋コンクリート柱のサージ特性は円筒の金

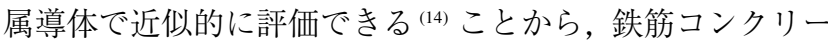
卜柱を長さ $2 \mathrm{~m}$, 直径 $35 \mathrm{~mm}$ のアルミパイプで模擬した。 縮小モデル実験では, 次の代表的な 2 ケースの配電線につ いてサージ特性の把握を行った。1つ目のケースは，電柱 に高圧電線 3 条のみを架線した配電線（以下，「架空地線が

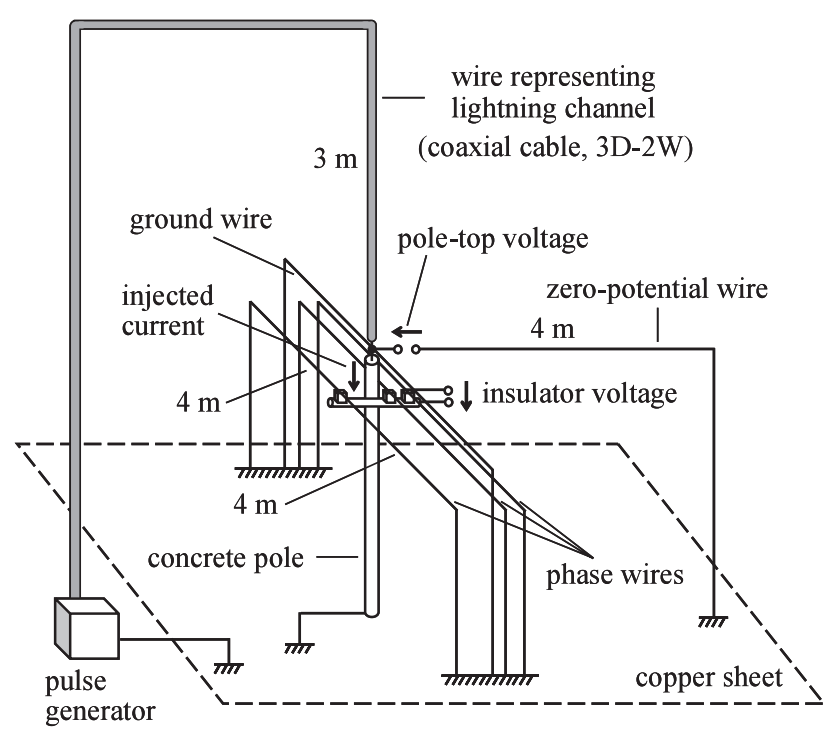

Fig. 1. Experimental setup.
ない配電線」と記す）であり，2つ目は，高圧電線 3 条と 架空地線 1 条を架線した配電線（以下，「架空地線がある配 電線」と記す）である。遠方に設置したパルス発生器によ り急峻波電流を発生させ，Fig. 1 に示すように同軸ケーブ ルを通して鉛直上方から電柱頂部に注入し，電柱頂部と零 電位線の間に発生する電圧（以下，「柱頂電位」と記す）お よび碍子間電圧を測定した。電流注入箇所では，同軸ケー ブル心線と電柱頂部の間に $540 \Omega$ の抵抗を直列に挿入して おり，同軸ケーブルの金属シースが雷道の模擬となる ${ }^{(15)}$ 。 模擬雷道のサージインピーダンスは 400 $500 \Omega$ 程度†であ り, 挿入抵抗 $540 \Omega$ および同軸ケーブルのサージインピー ダンス $50 \Omega$ と合わせて, 電柱からみた雷道側のサージイン ピーダンスはほぼ $1 \mathrm{k} \Omega$ となる。この值は，近年，観測結果 より得られた雷道インピーダンスの值に相当する ${ }^{(16)}$ 。

〈2・2〉 従来モデルの課題＼cjkstart従来モデル (4) では, 高圧電 線および架空地線を多相の分布定数線路モデルサで模擬し ており，電柱を単相の無損失分布定数線路モデルで模擬し ている。この従来モデルを用いた EMTP 解析により, 前述 の縮小モデル実験を再現した結果について述べる。Table 1

Table 1. Calculation conditions.

\begin{tabular}{|c|c|c|}
\hline Item & \multicolumn{2}{|c|}{ Conditions } \\
\hline \multicolumn{3}{|l|}{ [Distribution line] } \\
\hline \multirow{4}{*}{ Phase wires } & \multicolumn{2}{|l|}{ Copper wire } \\
\hline & Diameter & $1.8 \mathrm{~mm}$ \\
\hline & Height & $1.875 \mathrm{~m}$ \\
\hline & Conductor spacing & $70 \mathrm{~mm}, 148 \mathrm{~mm}$ \\
\hline \multirow{3}{*}{ Ground wire } & \multicolumn{2}{|l|}{ Copper wire } \\
\hline & Diameter & $1.0 \mathrm{~mm}$ \\
\hline & Height & $2.0 \mathrm{~m}$ \\
\hline Line model & \multicolumn{2}{|c|}{ Lossless CP-LINE model } \\
\hline \multicolumn{3}{|l|}{ [Concrete pole] } \\
\hline \multirow{2}{*}{ Surge impedance } & \multicolumn{2}{|c|}{$\begin{array}{l}267 \Omega \\
\text { (Distribution line without a ground wire) }\end{array}$} \\
\hline & \multicolumn{2}{|c|}{$\begin{array}{l}302 \Omega \\
\text { (Distribution line with a ground wire) }\end{array}$} \\
\hline Propagation speed & \multicolumn{2}{|c|}{$300 \mathrm{~m} / \mu \mathrm{s}$} \\
\hline Grounding resistance & \multicolumn{2}{|l|}{$0 \Omega$} \\
\hline Line model & \multicolumn{2}{|c|}{ Lossless CP-LINE model } \\
\hline \multicolumn{3}{|l|}{ [Lightning current] } \\
\hline Current waveform & \multicolumn{2}{|c|}{$i_{0}\left\{1-\exp \left(-t / \tau_{i}\right)\right\}, \tau_{i}=1.1 \mathrm{~ns}$} \\
\hline $\begin{array}{l}\text { Lightning channel } \\
\text { impedance }\end{array}$ & \multicolumn{2}{|l|}{$1,040 \Omega$} \\
\hline Ground resistivity & \multicolumn{2}{|l|}{$1.69 \times 10^{-8} \Omega \cdot \mathrm{m}$} \\
\hline
\end{tabular}

†雷道を模擬して雷撃点より垂直に立ち上げた導体のサージインピー ダンスについては，これまでに詳しい検討がなされていない。仮に， 雷撃点より水平に架線した模擬雷道を想定した場合, そのサージイン ピーダンスは $450 \Omega$ となることから, 垂直な模擬雷道のサージイン ピーダンスは $400 \sim 500 \Omega$ 程度と考えられる。尚，以降の計算におい ては $450 \Omega$ を用いている。

${ }^{\dagger} \mathrm{EMTP}-\mathrm{RV}{ }^{(13)}$ の分布定数線路モデルには，ある周波数での表皮効 果のみを再現する CP-LINE モデルと表皮効果の周波数特性を再現す る FD-LINE モデルがある。雷サージ解析では, 約 $10 \mathrm{kHz}$ 以上の周波 数領域を解析対象としており, この領域では線路定数がほぼ一定值に 収束することから, 周波数特性の模擬は重要ではない。本論文では, 計算原理が簡単で高速な CP-LINE モデルを用いている。 
に，主な計算条件を示す。電柱のサージインピーダンスに は，縮小モデル実験より得られた值 ${ }^{(12)}$ を用いており，注入 電流は次式で与える電流 $i(t)$ の電流源と雷道インピーダン スを模擬する抵抗の並列回路により模擬している。

$$
\begin{aligned}
& i(t)=i_{0}\left\{1-\exp \left(-t / \tau_{i}\right)\right\} \cdots \cdots \cdots \cdots \cdots \cdots \cdots \cdots \cdots \\
& \text { ただし, } i_{0}: i(t) \text { の収束值， } \tau_{i}: i(t) \text { の時定数 }
\end{aligned}
$$

波頭長約 $3 \mathrm{~ns}$ で立ち上がるステップ状の電流（以下，「ス テップ電流」と記す）を注入したときの碍子間電圧の測定 結果と計算結果を Fig. 2 に示す。同図 (a) には架空地線が ない配電線の結果を，(b)には架空地線がある配電線の結果 を示している。尚，注入したステップ電流波形を再現する $\tau_{i}$ は $1.1 \mathrm{~ns}$ となる。本論文では，比較のため，以降に示す 電圧および電流波形を注入電流収束值 $1 \mathrm{~A}$ 当たりに換算し て表示することとする。

Fig. 2(a)では，ピーク值はほぼ一致しているが，ピーク值 前後の波形が一致していない。ピーク值前では，計算結果 よりも測定結果の方が緩やかに上昇している。これは，電 柱近傍の電磁界が球面状に形成していくことにより，柱頂 電位が注入電流の立ち上がりよりも緩やかに上昇していく ためである。一方，単一サージインピーダンスの分布定数 線路モデルで電柱を模擬している EMTP 解析では，注入電 流の立ち上がりに比例して柱頂電位は上昇する。ピーク值 後では，計算結果よりも測定結果の方が緩やかに減少して いる。これは，前述の電位が緩やかに形成していく現象に 加えて，電柱に注入されたサージ電流が大地面で反射する ときに見かけ上高い接地抵抗值を示すためであり，大地面 に対する配置が電柱と同じ垂直である送電鉄塔のサージ特 性に関する研究 ${ }^{(17) \sim(20)}$ においても同様な現象が報告されて いる。

Fig. 2(b)では, Fig. 2(a)の差異に加え, ピーク值も一致し ていない。ピーク值は，計算結果よりも測定結果の方が大 きい值を示している。これは，実現象において碍子間電圧 を抑制する架空地線の効果（すなわち，架空地線と高圧電 線の結合により，架空地線を流れる電流が高圧電線の電位 を持ち上げる効果) が計算よりも小さいためである ${ }^{(20)}$ 。縮 小モデル実験にて架空地線電位と高圧電線電位の測定結果 から求めた結合率は，時間の経過に伴って上昇する過程を 経てから一定值に収束する傾向を示しており，初期の值は TEM（Transverse Electro-Magnetic）波仮定の值よりも小 さい ${ }^{(12)}$ 。一方，EMTPにおける分布定数線路モデルでは， TEM 波の電磁界分布を仮定した計算を行うため，瞬時に架 空地線と高圧電線の結合が形成される。

以上を要約すると，従来モデルでは，次に示す(1)〜(3)の 現象が考慮されていない。

(1) 電柱近傍の電磁界形成に伴って, 柱頂電位が注入電 流よりも緩やかに上昇していく現象。

(2) 電柱に注入されたサージ電流が大地面で反射すると きに見かけ上高い接地抵抗值を示す現象。

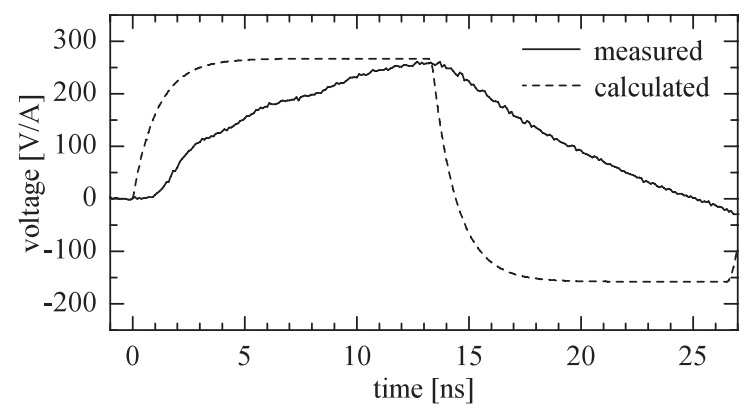

(a) Distribution line without a ground wire.

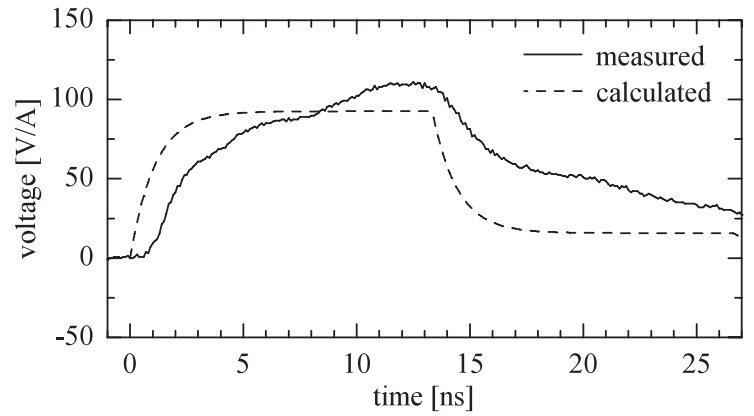

(b) Distribution line with a ground wire.

Fig. 2. Comparison between measured insulator voltages and calculated ones obtained by the conventional EMTP model.

(3) 架空地線と高圧電線の結合が時間の経過に伴って緩 やかに形成していく現象。

尚, Fig. 2 では, 計算結果よりも測定結果の方が $1.0 \mathrm{~ns}$ 程 度遅く立ち上がっている。この理由を次に示す。(i) 従来 モデルでは，注入電流がほぼ傾き $i_{0} / \tau_{i}$ で立ち上がる。これ に対して, 実際の注入電流は傾き 0 から徐々に立ち上がる ため, 測定結果にはこの立ち上がり遅れ約 $0.4 \mathrm{~ns} の$ 影響が 入る。（ii）従来モデルでは，高圧電線と電柱頂部間の電圧 を碍子間電圧として計算しており，計算結果は注入電流と 同時に立ち上がる。これに対して，実際の碍子間電圧は高 圧電線と高圧腕金間の電圧であり，測定結果は電柱頂部と 高圧腕金間の伝搬時間約 $0.5 \mathrm{~ns}$ が経過した後に立ち上がる。

\section{3. 配電線 EMTP 解析モデルの提案}

〈3・1〉提案モデルの概要 第 2 章で整理した従来モ デルの課題を踏まえ, 新たな配電線 EMTP 解析モデルを提 案する。Fig. 3 に提案モデルを示す。提案モデルは, 耐雷設 計上最も重要となる碍子間電圧 $V_{i 1}, V_{i 2}, V_{i 3}$ をできるだけ 正確に再現するように構築される。図中では，電柱の左右 両側に配置される架空地線，高圧電線をまとめて右側に示 している。本論文では, 架空地線がない配電線の計算を行 うための「提案モデル $\mathrm{A} 」 と$ 架空地線がある配電線の計算 を行うための「提案モデル B」の 2 種類を提案する。提案 モデルでは，電柱頂部および架空地線にキャパシタンスを 付加することでく2.2〉節の現象(1)を，電柱の定常接地抵抗 と直列に $R L$ 並列回路を付加することで現象(2，架空地 線と高圧電線の結合率の時間特性を模擬する電圧源を付加 


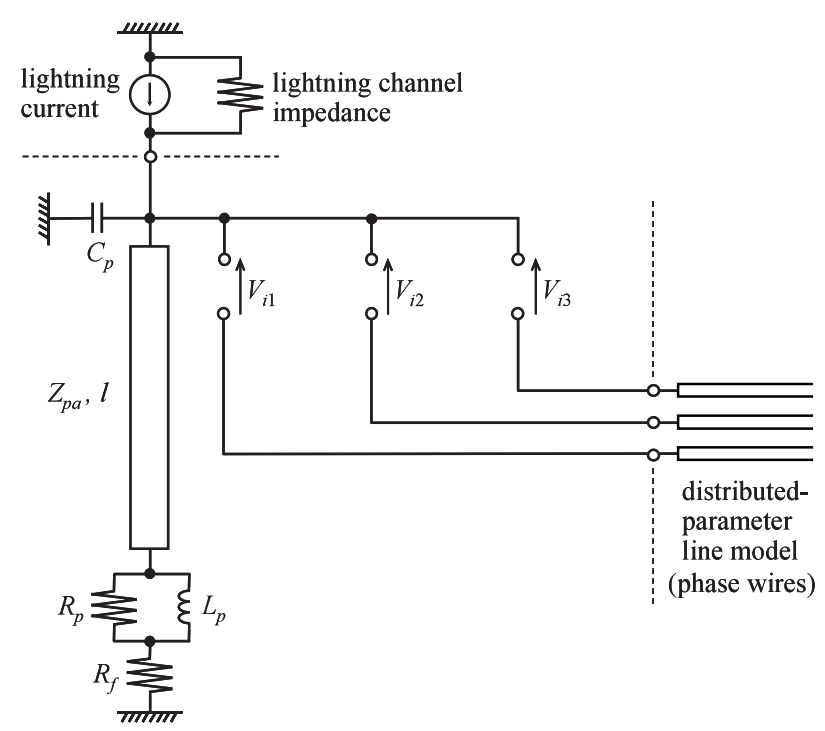

(a) Model A (without a ground wire)

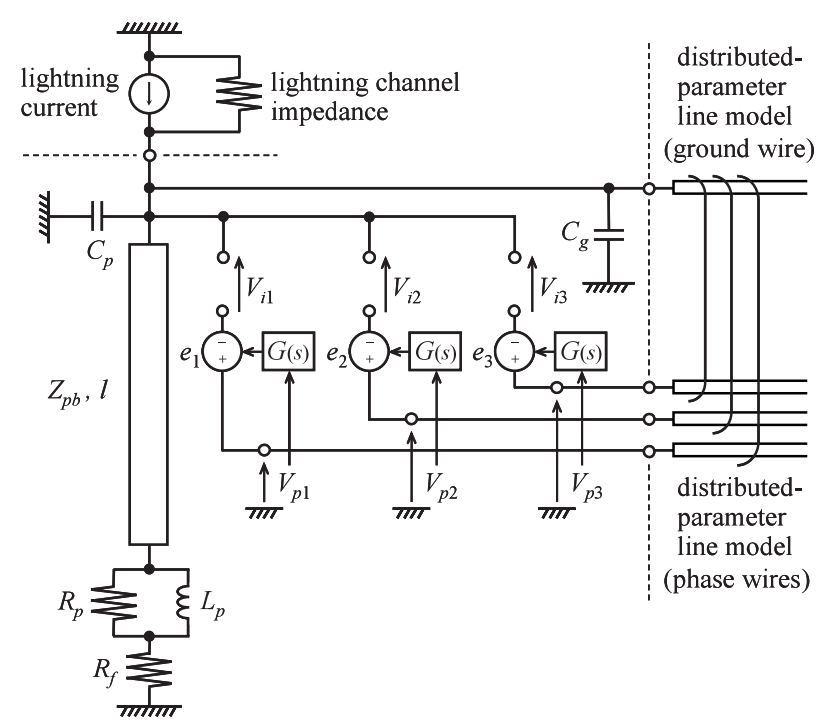

(b) Model B (with a ground wire)

Fig. 3. Proposed EMTP models of a distribution line.

することで現象(3)考慮している。提案モデルのパラメー 夕は，配電線のサージ実験結果を基に設定する。以下，縮 小モデル実験を例にとり，数值例も合わせてモデル化手順 を示す。以降の $\langle 3 \cdot 2\rangle \sim\langle 3 \cdot 4\rangle$ 節で示すモデルパラメータ は縮小モデルに対する数值である。

〈3·2〉 電柱のモデル 電柱のモデルは, 基本部分を 従来の単相の無損失分布定数線路モデルとしており，これ に本節で述べる新たな回路が付加されている。尚，提案モ デル A， B における無損失分布定数線路モデルのサージイ ンピーダンス $Z_{p a}, Z_{p b}$ は, 各々, 架空地線がない配電線お よび架空地線がある配電線のサージ実験より得られる電柱 のサージインピーダンス值とする。

$\langle\mathbf{3} \cdot \mathbf{2} \cdot \mathbf{1}\rangle$ 電柱の電位上昇の表現電柱頂部の電位は, 時間の経過に伴って緩やかに上昇する。この特性を近似的 に表現するため, キャパシタンス $C_{p}$ を電柱頂部に並列接 続する ${ }^{(11)} 。 C_{p}$ の值は, 架空地線がない配電線にステップ電

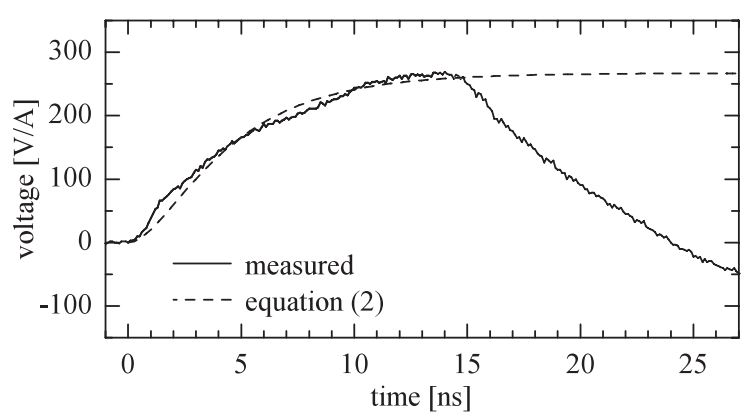

Fig. 4. Approximation of the pole-top voltage waveform by (2) (without a ground wire).

流を注入したときの柱頂電位の測定波形から決定する。縮 小モデル実験を例にとり， $C_{p}$ の決定方法について述べる。 架空地線がない配電線にステップ電流を注入したときの柱 頂電位の測定波形を Fig. 4 に示す。ここで, 注入電流を (1) 式とするとき, 無損失分布定数線路モデルとキャパシタン ス $C_{p}$ の組み合わせでモデル化された電柱の柱頂電位 $v(t)$ は, 次式で与えられる (付録 1 参照)。

$$
v(t)=v_{0}\left\{1-\frac{\tau_{i}}{\tau_{i}-\tau_{a}} \exp \left(\frac{-t}{\tau_{i}}\right)+\frac{\tau_{a}}{\tau_{i}-\tau_{a}} \exp \left(\frac{-t}{\tau_{a}}\right)\right\}
$$

ただし, $v_{0}: v(t)$ の収束值, $\tau_{a}:$ モデルの時定数

注入したステップ電流波形を (1) 式で最小二乗近似すると, $\tau_{i}=1.3 \mathrm{~ns}$ と求まる。 $\tau_{i}$ を用いて, Fig. 4 の柱頂電位ピー ク值までの立ち上がり部分を (2) 式で最小二乗近似すると, $\tau_{a}=3.6 \mathrm{~ns}$ が得られる。尚, $v_{0}$ の值は架空地線がない配電 線の実験にて得られた電柱のサージインピーダンス $Z_{p a}(=$ $267 \Omega)^{(12)}$ としている（本論文では，全ての波形を注入電流 収束值 $1 \mathrm{~A}$ 当たりに規格化しているため, サージインピーダ ンス值がそのまま電位上昇值になる)。Fig. 4 には，この近 似結果も合わせて示す。最終的に $C_{p}$ は次式で決定できる。

$$
C_{p}=\tau_{a} / Z_{p a}=13 \mathrm{pF}
$$

さて，このような電位上昇波形の変歪を模擬する方法は これまでにもいくつか検討されている。例えば，文献 (21) では, 周波数特性をもたせた線路により表現する周波数依 存鉄塔モデルが提案されている。このモデルは数值ラプラ ス変換と最小二乗法による近似を駆使した手法であり，モ デルパラメータの決定過程が非常に煩雑となる。一方, 提 案モデルは単純な $R C$ 並列回路により表現する手法である が, Fig. 4 に示すように波頭部の変歪を十分に精度良く再 現している。また，モデルパラメータについても測定波形 から直接的に決定できる。よって，提案モデルは周波数依 存鉄塔モデルよりも実用的に有用であるといえる。

〈3.2・2 〉 接地インピーダンスの表現電柱に注入さ れたサージ電流が大地面で反射するとき，見かけ上高い接 地抵抗值を示す。提案モデルでは，この現象を模擬する手 法として, 送電鉄塔の塔脚接地インピーダンスを模擬する 


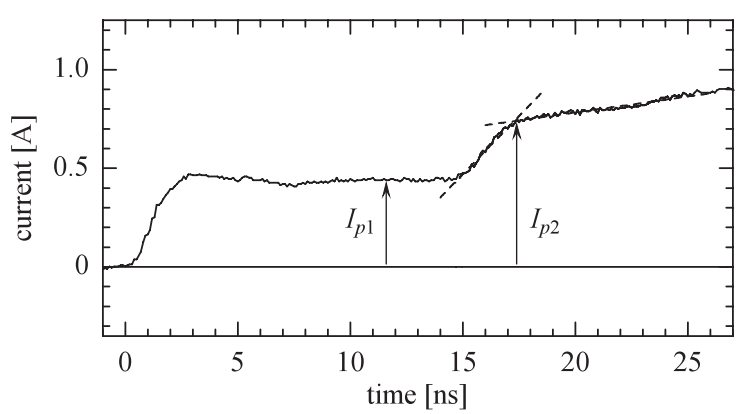

Fig. 5. Waveform of the current flowing into the pole.

ために考案された手法 ${ }^{(19)(20) を}$ 用いる。定常接地抵抗を表す 抵抗 $R_{f}$ と, 大地面反射時の見かけ上の高い接地抵抗值を 模擬する抵抗 $R_{p}$ とインダクタンス $L_{p}$ の並列回路により, 電柱の接地インピーダンス特性を模擬する。これにより， 電柱の接地抵抗は, 反射初期に示す高い接地抵抗值 $Z_{f}=$ $R_{f}+R_{p}$ から，時間の経過に伴って $R_{f}$ に収束していく。文 献 (19) では，架空地線を有する送電線の鉄塔塔頂にステッ プ電流を注入したときの鉄塔に流入する電流波形より $Z_{f}$ を 求める次式が示されている。

$\frac{I_{p 2}}{I_{p 1}}=1-\frac{Z_{f}-Z_{t w}}{Z_{t w}+Z_{f}} \cdot\left(1-\frac{Z_{e s}-Z_{t w}}{Z_{t w}+Z_{e s}}\right) \cdots$

ただし， $I_{p 1}$ : 大地面からの反射波が到達する前の 電流波高値, $I_{p 2}$ : 大地面からの反射波が塔頂で反射 した後の電流波高值, $Z_{t w}$ : 鉄塔のサージインピー ダンス, $Z_{e s}$ : 鉄塔からみた雷道インピーダンスと 架空地線のサージインピーダンスの等価的な合成 インピーダンス

鉄塔を電柱に置き換え，(4) 式を配電線に適用する。縮小モ デル実験を例にとり， $Z_{f}$ の值を求める。Fig. 5 に，架空地線 がある配電線にステップ電流を注入したときの電柱に流入 する電流波形を示す。同図より, $I_{p 1}=0.45 \mathrm{~A}, I_{p 2}=0.74 \mathrm{~A}$ が得られる $\left(I_{p 2}\right.$ の值は, 時刻 $15 \mathrm{~ns} \sim 17.5 \mathrm{~ns}$ の部分と時刻 $17.5 \mathrm{~ns} \sim 25 \mathrm{~ns}$ の部分を直線にて最小二乗近似し，その交点 より求めた)。 $Z_{t w}$ の值は, 架空地線がある配電線の実験に て得られた電柱のサージインピーダンス $Z_{p b}(=302 \Omega)^{(12)}$ とする。 $Z_{e s}$ は, 電柱からみた雷道側のインピーダンス $Z_{l}$ $(=1,040 \Omega)$ と実験より得られた架空地線のサージインピー ダンス $Z_{g}(=495 \Omega)^{(12)}$ を用いて次式より求まる。

$$
Z_{e s}=\frac{Z_{l} Z_{g} / 2}{Z_{l}+Z_{g} / 2}=200 \Omega
$$

最終的に, 各值を (4) 式に代入すると, $Z_{f}=91 \Omega$ と求まる。 縮小モデル実験では，大地面に抵抗を介さずに直接接続し ていることから， $R_{f}=0 \Omega$ である。これより， $R_{p}$ は次の值 となる。

$$
R_{p}=Z_{f}-R_{f}=91 \Omega
$$

$L_{p}$ の值は, 倸数 $k$ と電柱内のサージ伝搬時間 $\tau_{p}=l / c(l$ : 地 上部分の電柱長さ, $c$ : 光速 $)$ を用いて, 次式で決定できる。

$$
L_{p}=k \tau_{p} R_{p}
$$

$k$ の求め方については, $\langle 3 \cdot 4\rangle$ 節にて述べる。尚, 地上部分 の電柱長さ $l$ は $\tau_{p}$ に含まれることから,$k$ は $l$ にららい 係数となる。

$\langle\mathbf{3} \cdot \mathbf{2} \cdot \mathbf{3}\rangle$ 高圧腕金電位の表現 碍子間電圧は，高圧 腕金電位 (すなわち, 高圧腕金の取り付け位置における電柱 の電位) と高圧電線電位の差である。従って, 碍子間電圧 を正確に再現するためには, 高圧腕金電位を正確に模擬す る必要がある。電柱頂部よりも低い位置に取り付けられて いる高圧腕金の電位は, 柱頂電位よりも低下する。これは, 電柱頂部よりも雷電流の到来が遅れ，大地面からの反射波 の到来が早くなることに加えて，〈2·2〉節で述べたように, 電柱頂部や高圧腕金の電位が電磁界の形成に伴って緩やか に上昇していくことに起因する。一般的な高圧 1 回線の配 電線では, 電柱頂部と高圧腕金の間隔は $1 \mathrm{~m}$ 以下であり, 柱頂電位と高圧腕金電位の差異は僅かである†。これより, 柱頂電位と高圧腕金電位を等しい値と見なして, Fig. 6(a) に示すように電柱を 1 段の無損失分布定数線路モデルと電 柱の電位上昇の時間特性を表現するキャパシタンス $C_{p}$ の 組み合わせ（以下，単に「1 段モデル」と記す）で模擬し ても差し支えない。一方, 配電線が分岐する等の理由によ り, 電柱頂部と高圧腕金の間隔が $1 \mathrm{~m}$ よりも長くなる場合, 柱頂電位と高圧腕金電位の差異は大きくなる。このため, 1 段モデルを用いた碍子間電圧の計算結果は測定結果と一致 しなくなる。そこで, Fig. 6(b) に示すように無損失分布定 数線路モデルを $2 つ に$ 分割し, 柱頂電位と高圧腕金電位の 差異を表現する抵抗 $R_{a}$ とインダクタンス $L_{a}$ の並列回路を 加えた「2 段モデル」により, 電柱を模擬する。本論文で は, 電柱頂部と高圧腕金の間隔 $l_{1}=1 \mathrm{~m}$ を目安として, 1 段 モデルと 2 段モデルを使い分けることとするザ。Fig. 6 中 のカッコ内は, 提案モデル B に対するパラメータを表して いる。2段モデルのパラメータの決定方法を以下に示す。

提案モデル $\mathrm{A}$ における $R_{a}$ の值は, 架空地線がない配電線 にステップ電流を注入したときの柱頂電位ピーク值 $V_{t}(=$ $\left.Z_{p a}\right)$ と碍子間電圧ピーク值 $V_{i}$ より, 次式で決定する $\left(V_{t}\right.$, $V_{i}$ は, 注入電流収束值 $1 \mathrm{~A}$ 当たりに換算した值)。

$$
R_{a}=V_{t}-V_{i}
$$

$L_{a}$ の值は, 前節と同様, $k$ と $\tau_{p}$ を用いて次式で決定でき る。尚, 本節の $R L$ 並列回路と前節で述べた接地の $R L$ 並 列回路は, いずれも時間の経過に伴って電柱近傍の電磁界 が形成していくことに起因する現象を模擬する回路であるこ

\footnotetext{
†縮小モデル実験では, 架空地線がない配電線の柱頂電位と碍子間 電圧の差異が僅かであった (12)。架空地線がない配電線では, 雷電流に よる高圧電線電位の上昇はほとんどないと考えられるため, 碍子間電 圧う高圧腕金電位と見なせる。

$\dagger 2$ 段モデルは，モデルの構成要素が多いというデメリットがある。 加えて, 1 段モデルよりも時間刻みが細かくなるため, 計算時間が増 加する。従って, 本論文では基本形として 1 段モデルを推奨する。1 段モデルで近似できない場合のみ，2段モデルを用いる。
} 


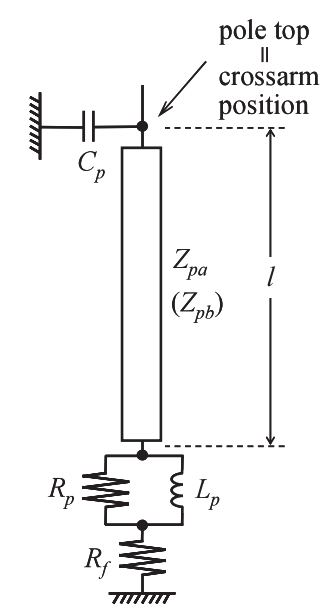

(a) Single story model

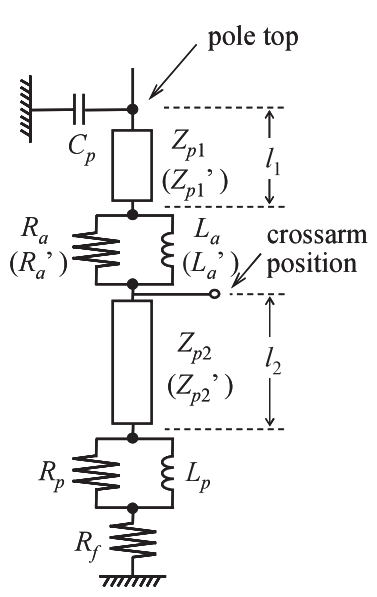

(b) Two story model
Fig. 6. Proposed models of a distribution pole.

とから，同じ時定数とした。

$$
L_{a}=k \tau_{p} R_{a}
$$

2 段の無損失分布定数線路モデルのサージインピーダンス $Z_{p 1}, Z_{p 2}$ は, 次式より求める。

$$
Z_{p 1}=Z_{p a}, \quad Z_{p 2}=Z_{p a}-R_{a}
$$

また，地上部分の電柱長さ $l$ と高圧腕金上下部分の電柱長 さ $l_{1}, l_{2}$ には, $l=l_{1}+l_{2}$ の関倸がある。

一方, 架空地線がある配電線では, 架空地線と高圧電線 の結合により高圧電線電位が上昇することから碍子間電圧 \# 高圧腕金電位となる。このため, (8) 式より提案モデル B に扔ける $R_{a}{ }^{\prime}$ の值を求めることができない。そこで，提案 モデル $\mathrm{A}$ の $R_{a}$ と提案モデル $\mathrm{A}, \mathrm{B}$ に扔ける電柱のサージ インピーダンス $Z_{p a}, Z_{p b}$ を用いて，次式より決定する。

$$
R_{a}{ }^{\prime}=\frac{R_{a} Z_{p b}}{Z_{p a}}
$$

また，提案モデル B におけるその他のパラメー夕は，次式 より求める。

$$
L_{a}{ }^{\prime}=k \tau_{p} R_{a}{ }^{\prime}, \quad Z_{p 1}{ }^{\prime}=Z_{p b}, \quad Z_{p 2}{ }^{\prime}=Z_{p b}-R_{a}{ }^{\prime}
$$

〈3・3〉架空地線, 高圧電線のモデル 架空地線, 高圧 電線のモデルとして, 提案モデル B のみに付加する回路に ついて述べる。尚，提案モデル A に扔ける高圧電線のモデ ルは従来どおり多相の分布定数線路モデルのみでよい。

〈3.3.1〉 架空地線の電位上昇の表現 架空地線の電 位は, 時間の経過に伴って上昇する過程を経てから TEM 波 仮定の值に収束していく。提案モデル B では, 電柱頂部に 接続する $C_{p}$ に加えて，この特性を近似的に表現するキャパ シタンス $C_{g}$ を架空地線と並列に接続する。架空地線があ る配電線にステップ電流を注入したときの柱頂電位の測定 波形から $C_{p}$ と $C_{g}$ の合成キャパシタンス $C_{t}\left(=C_{p}+C_{g}\right)$ を求め, これより $C_{g}$ の值を決定する。縮小モデル実験を

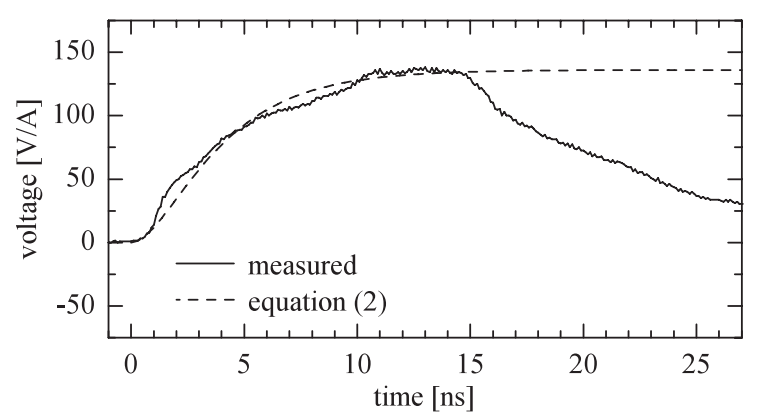

Fig. 7. Approximation of the pole-top voltage waveform by (2) (with a ground wire).

例にとり， $C_{g}$ の決定方法について述べる。架空地線がある 配電線にステップ電流を注入したときの柱頂電位の測定波 形を Fig. 7 に示す。注入したステップ電流波形を (1) 式で 最小二乗近似すると, $\tau_{i}=1.4 \mathrm{~ns}$ と求まる。ここで，(2) 式 の $\tau_{a}$ を $\tau_{b}$ に置き換えて考元， $\tau_{i}$ を用いて Fig. 7 の柱頂電 位ピーク值までの立ち上がり部分を (2) 式で最小二乗近似 すると， $\tau_{b}=2.9 \mathrm{~ns}$ が得られる。Fig. 7 には，この近似結 果も合わせて示す。次に, 架空地線がある配電線の電柱の サージインピーダンス $Z_{p b}$ と架空地線のサージインピーダ ンス $Z_{g}$ の合成インピーダンス $Z_{t}$ は, 実験より得られた值 $\left(Z_{p b}=302 \Omega, Z_{g}=495 \Omega\right)^{(12)}$ を用いて次式より求まる。

$$
Z_{t}=\frac{Z_{p b} Z_{g} / 2}{Z_{p b}+Z_{g} / 2}=136 \Omega
$$

これより， $C_{t}$ は次式で決定できる。

$$
C_{t}=\tau_{b} / Z_{t}=21 \mathrm{pF}
$$

最終的に, $\langle 3 \cdot 2 \cdot 1\rangle$ 節にて決定した $C_{p}=13 \mathrm{pF}$ を用いて, $C_{g}$ は次の値となる。

$$
C_{g}=C_{t}-C_{p}=8 \mathrm{pF}
$$

$\langle\mathbf{3 \cdot 3 \cdot 2 \rangle}$ 碍子間電圧を補正する電圧源架空地線が ある配電線の碍子間電圧を従来モデルにより計算すると, Fig. 2(b) に示すような計算結果と測定結果の差異が生じる。 これは，〈2·2〉節で述べたように, EMTPに打ける分布定数 線路モデルでは架空地線と高圧電線の結合が瞬時に形成さ れるのに対して, 実現象では時間の経過に伴って緩やかに 結合が形成していくためである。この碍子間電圧の差異を 補正するため, 提案モデル B では, Fig. 3(b) に示すように 電圧源 $e_{1}, e_{2}, e_{3}$ を各相の高圧電線の先端に接続する ${ }^{\dagger(11) 。 ~}$ これらの電圧源の值は, 架空地線に電流が流入したとき瞬 時に生じる TEM 波仮定の結合を打ち消して，時定数 $\tau_{c}$ で 徐々に結合が形成するように設定する。Fig. 3(b) に示すよ うに, 各相の高圧電線電位 $V_{p 1}, V_{p 2}, V_{p 3}$ を入力として, 次 式の時定数 $\tau_{c}$ をもつ伝達関数 $G(s)$ の応答を求め, これと

\footnotetext{
${ }^{\dagger} \mathrm{EMTP}^{\mathrm{R} V^{(13)}}{ }^{(13)}$ よ以前のバージョンでは, Fig.3(b) に示すように ノード間に電圧源を接続することが不可能である。このような場合に は, 理想変圧器を用いてノード間の電圧を設定する等の工夫が必要と なる。
} 


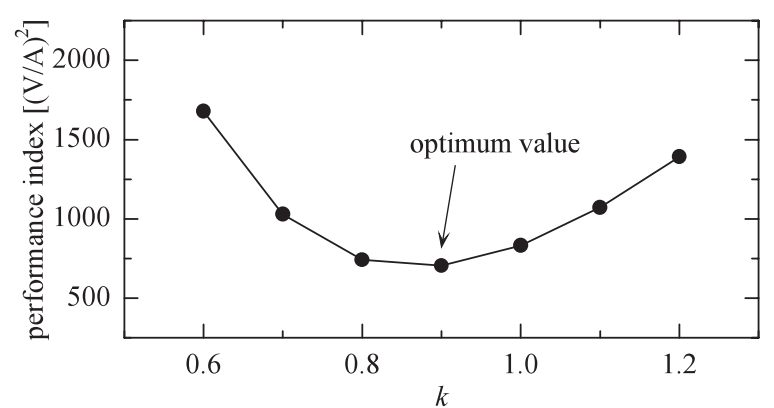

Fig. 8. Relationship between $k$ and performance index.

逆位相の電圧を $e_{1}, e_{2}, e_{3}$ として発生させる。

$$
G(s)=1-\frac{1}{1+\tau_{c} s} .
$$

架空地線がある配電線では, 垂直導体である電柱と水平導 体である架空地線と高圧電線の現象が混在して観測される ことから，配電線のサージ実験結果を用いて $\tau_{c}$ を直接的に 決定することは難しい。このため, $\tau_{c}$ の決定方法について は, $\langle 3 \cdot 2 \cdot 2\rangle$ 節で述べた $k$ の決定方法と合わせて $\langle 3 \cdot 4\rangle$ 節 にて述べる。

$\langle\mathbf{3} \cdot \mathbf{4}\rangle \quad \boldsymbol{k}$ と $\boldsymbol{\tau}_{\boldsymbol{c}}$ の決定方法 ここまでで, $k$ と $\tau_{c}$ を除 いた提案モデルのパラメー夕を決定できた。 $k$ と $\tau_{c}$ の值は, これらの值を変化させながら提案モデルを用いた EMTP解 析を行い, 碍子間電圧の計算結果と測定結果の差異が最も 小さくなる条件にて決定することとする。尚，送電鉄塔の モデル化に関する研究 ${ }^{(19)(20)} に$ に扔いても，一部試行錯誤によ るモデルパラメータの決定過程がとられている。しかしな がら，本論文にて提案するモデルでは，縮小モデル実験よ り得られる $k$ と $\tau_{c}$ を実規模配電線における $k$ と $\tau_{c} （ \tau_{c}$ は 時間領域のパラメータであるため, 縮尺の逆数を乗じて実 規模に換算する必要がある）として用いることが可能であ り, 今後, 試行錯誤の過程を経ずにモデルパラメータを一意 に決定することができる。これは，縮小モデル実験が，我 が国に拀ける標準的な高圧 1 回線の配電線をできるだけ正 確に再現して実施したサージ実験であり，縮尺 6.3 分の 1 の配電線では，実規模配電線に生じるサージ現象と同様な サージ現象が 6.3 分の 1 に短縮されたタイミングで生じる ためである。

先ず，架空地線がない配電線の測定結果と提案モデル A を用いた計算結果から $k$ の值を求める。碍子間電圧波形の ピーク值および時刻 $4 \tau_{p}$ （2 往復伝搬時間）の值について, 計算結果と測定結果の差分を求めて 2 乗し，その総和を評 価値とする。縮小モデル実験では, 注入電流の波頭長 $T_{f}$ をステップ状から， $16 \mathrm{~ns}(0.1 \mu \mathrm{s}), 32 \mathrm{~ns}(0.2 \mu \mathrm{s}), 48 \mathrm{~ns}$ $(0.3 \mu \mathrm{s})$ と変化させて抢り, 全ての注入電流に対する評価 值を総計した。尚，カッコ内は実規模換算の波頭長の值で ある。 $k$ を変化させたときの評価值の変化を Fig. 8 に示す。 これより， $k=0.9$ と求まる。

次に，架空地線がある配電線の測定結果と提案モデル B を用いた計算結果から $\tau_{c}$ の值を求める。尚， $k$ は前述で求

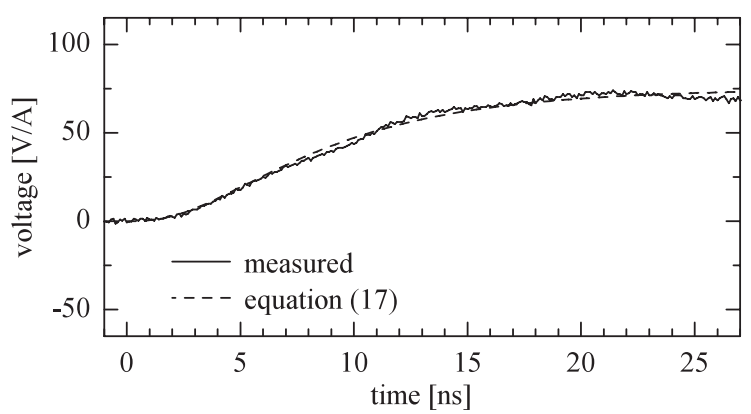

Fig. 9. Approximation of the phase wire voltage waveform by Eq. (17) (without a pole).

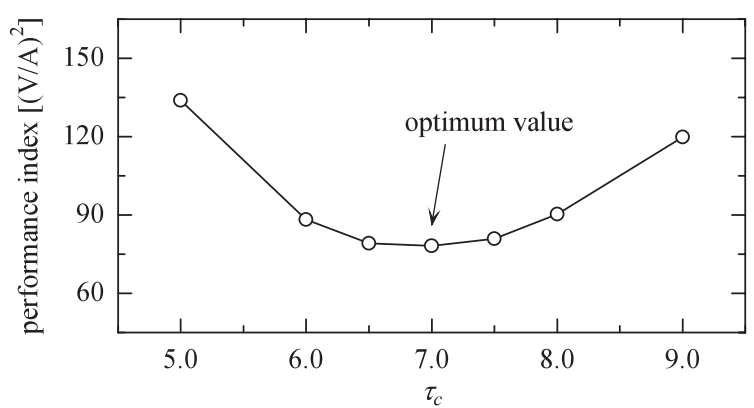

Fig. 10. Relationship between $\tau_{c}$ and performance index.

めた值を用いる。ここで, EMTP 解析の計算量を少なくす るため, 架空地線と高圧電線のみの状態㧍ける高圧電線電 位の測定結果から，目安となる時定数 $\tau_{c}{ }^{\prime}$ を求める。Fig. 1 の実験配置にて, 電柱を取り除き架空地線と高圧電線のみ の状態とし，架空地線にステップ電流を注入したときの高 圧電線電位の測定波形を Fig. 9 に示す。注入電流を (1) 式 とするとき, 分布定数線路モデルとキャパシタンス $C_{g}$ の組 み合わせでモデル化された架空地線との結合により生じる 高圧電線電位 $v_{p n}(t)$ は，次式で与えられる (付録 2 参照)。 尚, 添え字 $n=1 ， 2 ， 3$ は，高圧電線の 3 相それぞれを表 現している。

$$
\begin{aligned}
v_{p n}(t)= & v_{p n 0}\left\{1-\frac{\tau_{i}^{2}}{\left(\tau_{i}-\tau_{g}\right)\left(\tau_{i}-\tau_{c}{ }^{\prime}\right)} \exp \left(\frac{-t}{\tau_{i}}\right)\right. \\
& +\frac{\tau_{g}^{2}}{\left(\tau_{i}-\tau_{g}\right)\left(\tau_{g}-\tau_{c}{ }^{\prime}\right)} \exp \left(\frac{-t}{\tau_{g}}\right) \\
& \left.-\frac{\tau_{c}{ }^{2}}{\left(\tau_{i}-\tau_{c}{ }^{\prime}\right)\left(\tau_{g}-\tau_{c}{ }^{\prime}\right)} \exp \left(\frac{-t}{\tau_{c}{ }^{\prime}}\right)\right\} \ldots \cdots
\end{aligned}
$$

ただし， $v_{p n 0}: v_{p n}(t)$ の収束値， $\tau_{g}\left(=C_{g} Z_{g}\right):$ 架 空地線モデルの時定数

注入したステップ電流波形を (1) 式で最小二乗近似すると, $\tau_{i}=1.5 \mathrm{~ns}$ と求まる。 $\tau_{i}$ を用いて, Fig. 9 の高圧電線電位 を(17) 式で最小二乗近似すると, $\tau_{c}{ }^{\prime}=6.1 \mathrm{~ns}$ が得られる。 Fig. 9 には，この近似結果も合わせて示す。得られた $\tau_{c}{ }^{\prime}$ の 值を目安として， $\tau_{c}$ を変化させたときの評価值の変化を Fig. 10 に示す。これより， $\tau_{c}=7.0 \mathrm{~ns}$ と求まる。尚， $\tau_{c}$ が $\tau_{c}{ }^{\prime}$ よりも約 $15 \%$ 大きな值となったことについては，電柱 
Table 2. Estimated model parameters of an actual- scale distribution line.

\begin{tabular}{c|l|l|c}
\hline \multicolumn{2}{c}{ Item } & Conditions \\
\hline \multirow{4}{*}{ Model A } & \multirow{2}{*}{ Concrete pole } & $Z_{p a}$ & $267 \Omega$ \\
\cline { 2 - 4 } & & $C_{p}$ & $82 \mathrm{pF}$ \\
\cline { 2 - 4 } & \multirow{2}{*}{$\begin{array}{l}\text { Grounding } \\
\text { resistance }\end{array}$} & $R_{p}$ & $91 \Omega$ \\
\cline { 3 - 4 } & $L_{p}$ & $3.4 \mu \mathrm{H}$ \\
\hline \multirow{4}{*}{ Model B } & \multirow{2}{*}{ Concrete pole } & $Z_{p b}$ & $302 \Omega$ \\
\cline { 3 - 4 } & & $C_{p}$ & $82 \mathrm{pF}$ \\
\cline { 3 - 4 } & Ground wire & $C_{g}$ & $50 \mathrm{pF}$ \\
\cline { 2 - 4 } & Phase wires & $\tau_{c}$ & $44 \mathrm{~ns}$ \\
\cline { 2 - 4 } & \multirow{2}{*}{$\begin{array}{l}\text { Grounding } \\
\text { resistance }\end{array}$} & $R_{p}$ & $91 \Omega$ \\
\cline { 3 - 4 } & $L_{p}$ & $3.4 \mu \mathrm{H}$ \\
\hline
\end{tabular}

の存在により電磁界が散乱され, 架空地線と高圧電線の結 合の形成が更に緩やかになったためと考えられる。

$\langle\mathbf{3} \cdot \mathbf{5}\rangle$ 実規模配電線のモデルパラメータ 以上で, 配電線の縮小モデルを用いたサージ実験結果より，配電線 EMTP 解析モデルのパラメータを全て決定することができ た。〈3・2〉〜〈3.4 節に示したモデルパラメータは縮小モデ ルに対する数值であることから，ここでは，実規模の配電 線を想定した場合にどの程度の数值となるかをみることに する。縮小モデル実験の時間軸を 6.3 倍とすることで等価 的に原寸の配電線における結果と考えることができること から，縮小モデルに対して求めた時定数 $\tau_{a}, \tau_{b}, \tau_{c}, \tau_{p}$ を 6.3 倍する。これより, 実規模の配電線に対するキャパシタ ンス $C_{p}, C_{g}$ およびインダクタンス $L_{p}$ は 6.3 倍された数值 となる。Table 2 に，縮小モデルの装柱で考えた場合の実規 模配電線のモデルパラメータを示す。尚，電柱のサイズや 装柱等が変われば，モデルパラメータの決定に必要なデー 夕を取得するために，配電線のサージ実験を改めて行う必 要がある。また，実験に代えて，近年，雷サージ解析に用 いられるようになってきた数值電磁界解析手法を適用する ことも有効な手段と考えられる ${ }^{(10)}$ 。

\section{4. 提案モデルを用いた EMTP 解析}

$\langle 3 \cdot 2\rangle \sim\langle 3 \cdot 4\rangle$ 節で決定したモデルパラメータ值を用いた 提案モデルにより，縮小モデル実験を再現する。縮小モデ ル実験における電柱頂部と高圧腕金の間隔は，実規模に換 算すると約 $1 \mathrm{~m}$ であり，電柱モデルには 1 段モデルを用い た。主な計算条件は, Table 1 のとおりである。

$\langle\mathbf{4} \cdot \mathbf{1}\rangle$ 提案モデル A による計算結果 架空地線がな い配電線において, 注入電流の波頭長 $T_{f}$ を変化させたとき の碍子間電圧を計算する。測定結果および提案モデル A を 用いた計算結果を各々 Fig. 11，Fig. 12 に示す。Fig. 12(b) の計算結果では，Fig. 2(a)に見られた碍子間電圧ピーク值 前後の差異がなくなり, Fig. 11(b) の測定結果を良く再現し ている。

〈4・2〉提案モデル B による計算結果 架空地線があ る配電線において, 注入電流の波頭長 $T_{f}$ を変化させたとき

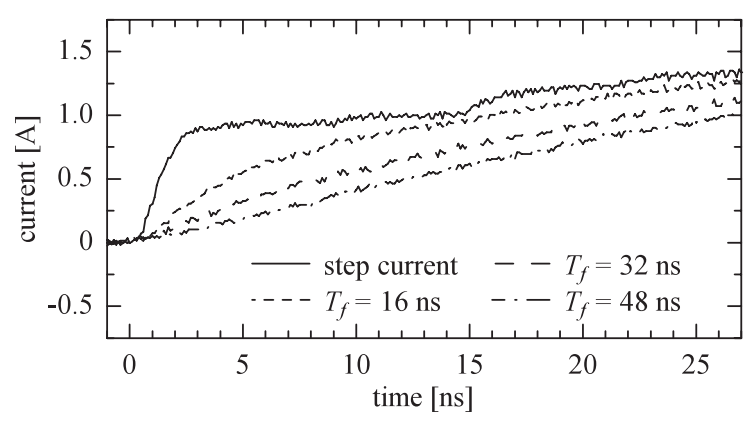

(a) Injected current

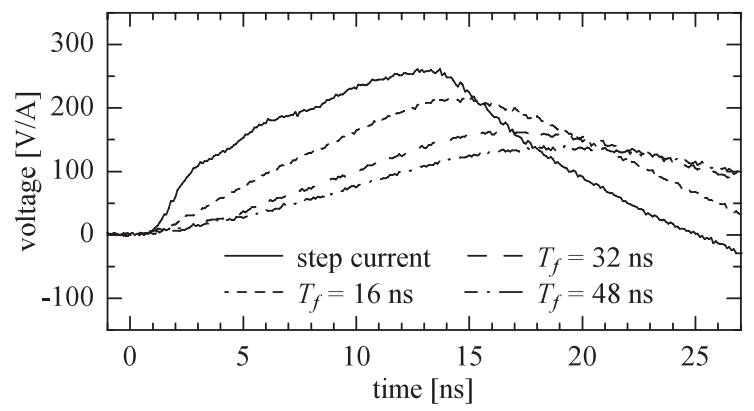

(b) Insulator voltage

Fig. 11. Measured results of the distribution line without a ground wire.

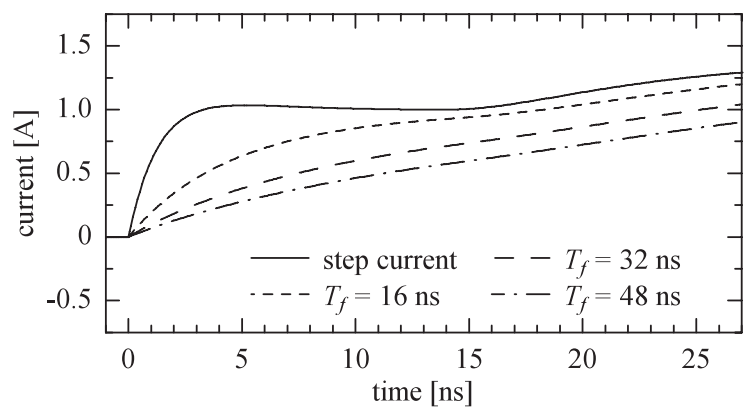

(a) Injected current

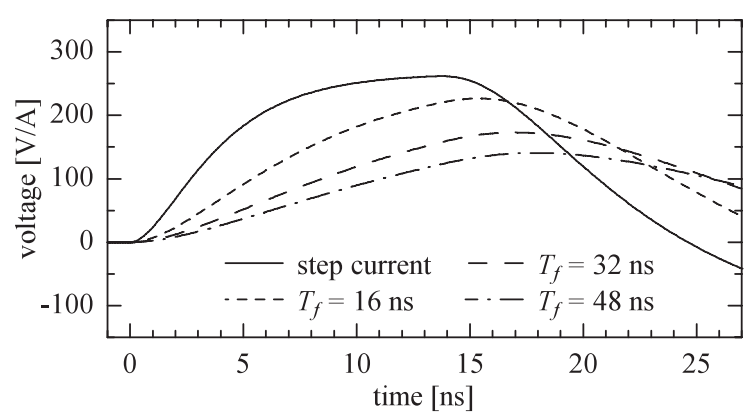

(b) Insulator voltage

Fig. 12. Calculated results using Model A (without a ground wire).

の碍子間電圧を計算する。測定結果および提案モデル B を 用いた計算結果を各々 Fig. 13, Fig. 14 に示す。Fig. 14(c) に示す碍子間電圧の計算結果では, Fig. 2(b) に見られた碍 子間電圧ピーク值の差異がなくなり, Fig. 13(c) の測定結 果を良く再現している。たたし，ステップ電流を注入した ときのピークが早い時刻で出ている。これは, 本来一体と なって生じている〈2・2〉節で述べた(1)（3)の現象を別々に 


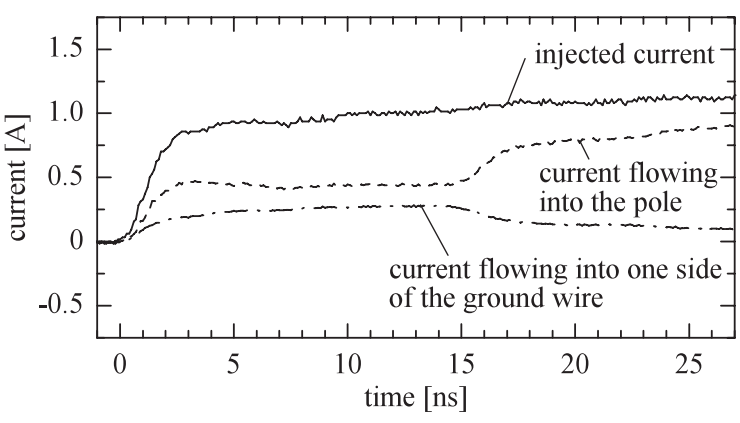

(a) Currents at various positions for step-current injection

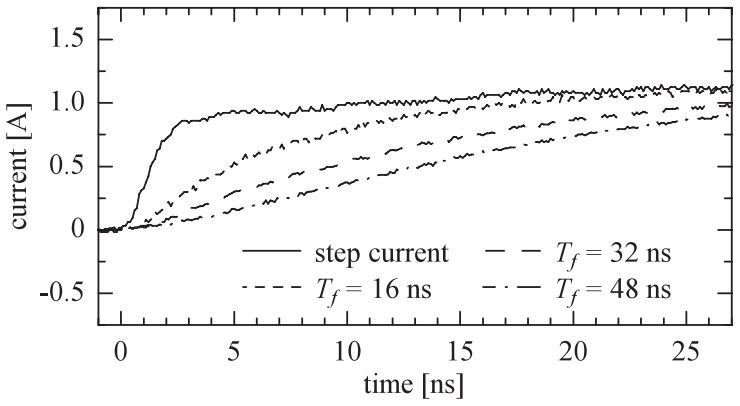

(b) Injected current

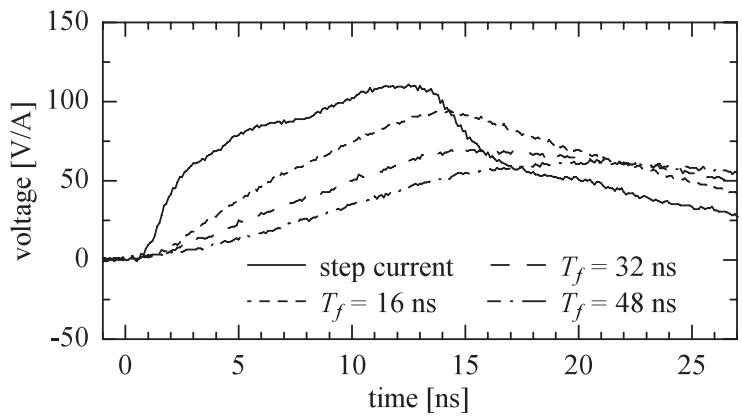

(c) Insulator voltage

Fig. 13. Measured results of the distribution line with a ground wire.

模擬していることにより，立ち上がり部分で(3)現象（架 空地線と高圧電線の結合が緩やかに形成していく現象）を 模擬する電圧源の影響が強めに出たためと考えられる。す なわち, 立ち上がり部分で高圧電線の電位上昇が必要以上 に緩やかとなり, 結果として, 柱頂電位と高圧電線電位の 差分である碍子間電圧が大きくなっている。しかしながら， ステップ電流を注入したときの測定結果と計算結果は全体 として極端に違わないこと，並びに，実用的な波頭長であ る $T_{f}=16 \mathrm{~ns}$ 以上の計算結果は測定結果を再現しているこ と等から，提案モデルは実用的に十分な解析精度を有して いるといえる。

\section{5. おわりに}

本論文では，筆者らが実施した縮小モデル実験にて得ら れた知見を基に，従来モデルでは算定できなかった短時間 領域における配電線の碍子間電圧を正確に再現できる新た な EMTP 解析モデルを提案した。提案モデルは，急峻な雷 電流に対して実用的に十分な解析精度を有している。今後

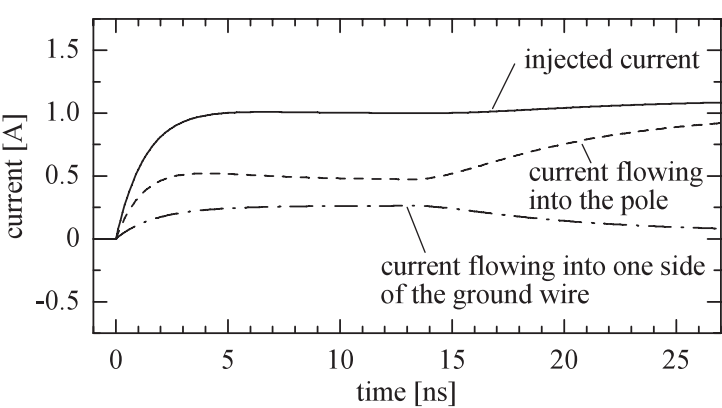

(a) Currents at various positions for step-current injection

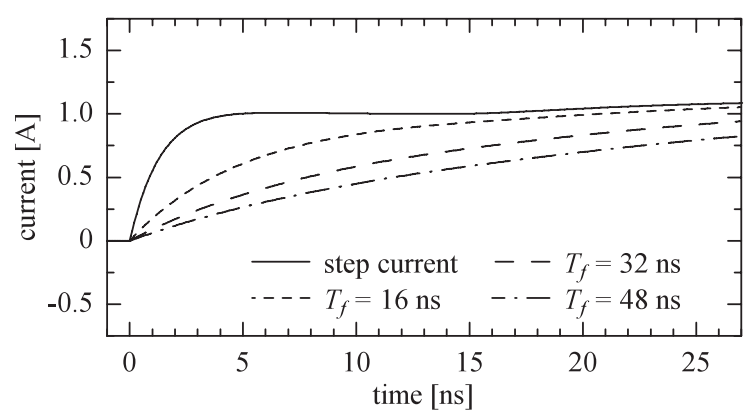

(b) Injected current

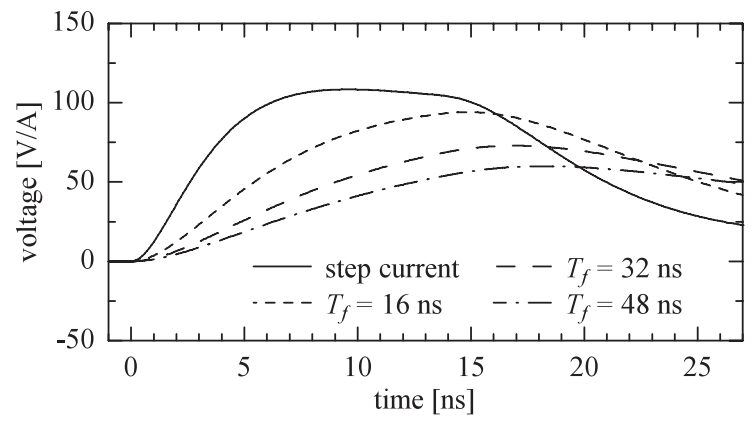

(c) Insulator voltage

Fig. 14. Calculated results using Model B (with a ground wire).

は，提案モデルと碍子のスパークオーバのモデルとの組み 合わせについて検討を行いたい。

(平成 19 年 11 月 21 日受付，平成 20 年 4 月 12 日再受付)

$$
\text { 文献 }
$$

(1) S. Yokoyama: "Analytical and Corroborative Study on Over-voltages Induced on Power Distribution Line Due to Nearby Lightning Strokes", CRIEPI Report, No.123 (1986) (in Japanese)

横山 茂：「配電線誘導雷現象の解析とその実証」, 電中研総合報告, No.123 (1986)

(2) Subcommittee for Power Distribution Systems, Lightning Protection Design Committee: "Guide of Lightning Protection Design for Power Distribution Lines", CRIEPI Report, No.T69 (2002) (in Japanese) 耐雷設計委員会 配電分科会：「配電線耐雷設計ガイド」, 電中研総合 報告，No.T69 (2002)

(3) Y. Imai, T. Matsuura, K. Itoh, S. Ishibe, M. Azuma, and T. Shimomura: "Protective Effects of Surge Arresters on Power Distribution Lines against Direct Lightning Hits to Overhead Ground Wire", T. IEE Japan, Vol.111-B, No.6, pp.619-627 (1991-6) (in Japanese)

今井康友 - 松浦達吉 - 伊東和美 - 石辺信治 - 東 正弘 - 下村哲朗 : 「架空地線直撃雷に対する配電用避雷器の保護効果」, 電学論 $\mathrm{B}, \mathbf{1 1 1}$, 6, pp.619-627 (1991-6)

(4) N. Fujiwara, T. Yoneyama, Y. Hamada, T. Yokota, A. Asakawa, T. Shimomura, K. Yamaoka, and S. Ishibe: "Lightning Overvoltage Protective Effect of Distribution Line Arresters", T. IEE Japan, Vol.115-B, No.11, pp.1284-1290 (1995-11) (in Japanese) 
藤原信行 · 米山 司 · 濱田義之 · 横田 勤 ・ 浅川 聡 - 下村哲朗 山岡浩一・石辺信治 :「配電用避雷器の雷過電圧抑制効果」, 電学論 B, 115, 11, pp.1284-1290 (1995-11)

(5) K. Nakada, T. Yokota, S. Yokoyama, A. Asakawa, M. Nakamura, H. Taniguchi, and A. Hashimoto: "Energy Absorption of Surge Arresters on Power Distribution Lines due to Direct Lightning Strokes - Effects of an Overhead Ground Wire and Installation Position of Surge Arresters - " IEEE Trans. Power Delivery, Vol.12, No.4, pp.1779-1785 (1997-10)

(6) H. Sugimoto, A. Asakawa, S. Yokoyama, and K. Nakada: "Evaluation of Installing Two Sets of Distribution Surge Arresters in Parallel on a Single Pole as a Method for Preventing Distribution Surge Arrester Damages", $T$. IEE Japan, Vol.121-B, No.6, pp.795-802 (2001-6) (in Japanese) 杉本仁志・浅川 聡・横山 茂・ 中田一夫 : 「配電用避雷器の並列 施設による避雷器雷焼損防止策の検討」, 電学論 B, 121, 6, pp.795-802 (2001-6)

(7) T. Miyazaki, S. Okabe, K. Aiba, T. Hirai, and J. Yoshinaga: "A Study on the Practical Grounding System in Power Distribution Lines", IEEJ Trans. PE, Vol.127, No.2, pp.424-431 (2007-2) (in Japanese)

宮崎 輝・岡部成光·饗場 潔・平井崇夫·吉永 淳:「設備実態を考 慮した配電線接地設計の検討」, 電学論 B, 127, 2, pp.424-431 (2007-2)

(8) T. Miyazaki, S. Okabe, K. Aiba, T. Hirai, and J. Yoshinaga: "A Lightning Surge Analysis for the Rationalization of the Grounding System in Power Distribution Lines", IEEJ Trans. PE, Vol.127, No.2, pp.432-440 (2007-2) (in Japanese) 宮崎 輝・岡部成光·饗場 潔・平井崇夫·吉永 淳 : 「配電接地合 理化に向けた雷過電圧解析」, 電学論 B, 127, 2, pp.432-440 (2007-2)

(9) T. Narita, T. Yamada, A. Mochizuki, E. Zaima, and M. Ishii: "Observation of Current Waveshapes of Lightning Strokes on Transmission Towers", IEEE Trans. Power Delivery, Vol.15, No.1, pp.429-435 (2000-1)

(10) Special Issue: "Recent Development and Future Prospects of Technologies on Lightning Surge Analysis", IEEJ Journal, Vol.126, No.10, pp.654-673 (2006-10) (in Japanese)

電気学会誌特集記事 :「雷サージ解析技術の現状と将来展望」, 電学 誌, 126, 10, pp.654-673 (2006-10)

(11) T. Noda: "A Tower Model for Lightning Overvoltage Studies Based on the Result of an FDTD Simulation", IEEJ Trans. PE, Vol.127, No.2, pp.379388 (2007-2) (in Japanese)

野田 玩:「FDTD 解析の結果に基づく雷サージ解析用鉄塔モデル」, 電学論 B, 127, 2, pp.379-388 (2007-2)

(12) S. Matsuura, T. Noda, A. Asakawa, and S. Yokoyama: "An Experimental Study of Surge Characteristics of a Distribution Line Using a Reduced-Scale Model", IEEJ Trans. PE, Vol.128, No.1, pp.226-234 (2008-1) (in Japanese) 松浦 進・野田 玩・浅川 聡・横山 茂:「縮小モデルを用いた配 電線のサージ特性に関する実験的検討」, 電学論 B, 128, 1, pp.226-234 (2008-1)

(13) http://www.emtp.com/

(14) K. Yamamoto, Z. Kawasaki, K. Matsuura, S. Sekioka, and S. Yokoyama "Surge Impedances of Concrete Pole and Grounding Lead Wire in Distribution Line by a Scale Model Technique", T. IEE Japan, Vol.119-B, No.7, pp.861-870 (1999-7) (in Japanese)

山本賢司・河崎善一郎・松浦虔士・関岡昇三・横山 茂:「縮小モデ ルによる配電線コンクリート柱および接地線のサージインピーダン スの検討」, 電学論 B, 119, 7, pp.861-870 (1999-7)

(15) M.A.A. Wahab and I. Matsubara: "Surge Impedance of Mono-Pole Tower", Technology Reports of the Osaka University, Vol.37, No.1876, pp.97-104 (1987-3)

(16) Investigating R\&D Committee on Lightning Parameters for Insulation and Protection Designs of Power Systems: "Lightning Parameters for Insulation and Protection Designs of Power Systems”, IEEJ Technical Report, No.1033 (2005) (in Japanese)

電力設備のための雷パラメー夕選定方法調査専門委員会：「電力設備 のための雷パラメータの選定法」, 電気学会技術報告, No.1033 (2005)

(17) W.A. Chisholm and W. Janischewskyj: "Lightning Surge Response of Ground Electrodes", IEEE Trans. Power Delivery, Vol.4, No.2, pp.1329$1337(1989-4)$

(18) S. Kato, R. Elarbi, A. Mochizuki, and E. Zaima: "Surge Response Analysis of Tower Grounding by Numerical Electromagnetic Field Analysis", T. IEE Japan, Vol.115-B, No.8, pp.970-977 (1995-8) (in Japanese)

加藤正平・Rajab Elarbi 望月 東・財満英一: 「鉄塔接地サージ特性 の数值電磁界解析」, 電学論 B, 115, 8, pp.970-977 (1995-8)

(19) Y. Baba and M. Ishii: "Tower Models for Fast-Front Lightning Currents", $T$. IEE Japan, Vol.120-B, No.1, pp.18-23 (2000-1)

(20) Y. Baba and M. Ishii: "Numerical Electromagnetic Field Analysis on Lightning Surge Response of Tower with Shield Wire", IEEE Trans. Power Delivery, Vol.15, No.3, pp.1010-1015 (2000-7)

(21) N. Nagaoka: "A Development of Frequency-Dpendent Tower Model", $T$.
IEE Japan, Vol.111-B, No.1, pp.51-56 (1991-1) (in Japanese)

長岡真人:「周波数依存鉄塔モデルの開発」, 電学論 B, 111, 1, pp.51-56 (1991-1)

\section{付 録}

\section{1. 電柱の過渡応答の模擬}

提案モデルでは，電柱の過渡応答を $R C$ 並列回路により 模擬しており， $R C$ 並列回路に発生する電圧が提案モデル の柱頂電位に相当する。(1) 式で与えられる $R C$ 並列回路に 注入される電流をラプラス変換し， $\tau_{a}=R C$ とすると発生 電圧として次式を得る。

$$
\begin{array}{r}
V(s) \\
=V_{0}\left\{\frac{1}{s}-\frac{\tau_{i}}{\left(\tau_{i}-\tau_{a}\right)\left(s+1 / \tau_{i}\right)}+\frac{\tau_{a}}{\left(\tau_{i}-\tau_{a}\right)\left(s+1 / \tau_{a}\right)}\right\} \\
\ldots \ldots \ldots \ldots \ldots \text { (付 } 1)
\end{array}
$$

(付 1) 式を逆ラプラス変換することにより，(2) 式が得ら れる。

\section{2. 高圧電線の過渡応答の模擬}

提案モデル B では，電柱と同様，架空地線の過渡応答 も $R C$ 並列回路により模擬している。 $R C$ 並列回路を app. Fig. 1 に示す。提案モデル B の架空地線を流れる電流は, 図 中の $i_{2}(t)$ に相当する。架空地線と高圧電線の結合により, この $i_{2}(t)$ が高圧電線の電位を持ち上げることになる。 $R C$ 並列回路に注入される電流 $i_{1}(t)$ を (1) 式で与え, $\tau_{g}=R C$ として $i_{2}(t)$ をラプラス変換すると次式を得る。

$$
I_{2}(s)=\frac{I_{0}}{s\left(1+\tau_{g} s\right)\left(1+\tau_{i} s\right)} .
$$

(付 2) 式に $Z_{m} /\left(1+\tau_{c}{ }^{\prime} s\right)$ を乗じることにより, 時定数 $\tau_{c}{ }^{\prime}$ で立ち上がる高圧電線電位として次式を得る。

$$
\begin{aligned}
V_{p n}(s)= & \frac{V_{p n 0}}{s\left(1+\tau_{g} s\right)\left(1+\tau_{i} s\right)\left(1+\tau_{c}{ }^{\prime} s\right)} \\
= & V_{p n 0}\left\{\frac{1}{s}-\frac{\tau_{i}^{2}}{\left(\tau_{i}-\tau_{g}\right)\left(\tau_{i}-\tau_{c}{ }^{\prime}\right)\left(s+1 / \tau_{i}\right)}\right. \\
& +\frac{\tau_{g}^{2}}{\left(\tau_{i}-\tau_{g}\right)\left(\tau_{g}-\tau_{c}{ }^{\prime}\right)\left(s+1 / \tau_{g}\right)} \\
& \left.-\frac{\tau_{c}{ }^{2}}{\left(\tau_{i}-\tau_{c}{ }^{\prime}\right)\left(\tau_{g}-\tau_{c}{ }^{\prime}\right)\left(s+1 / \tau_{c}{ }^{\prime}\right)}\right\} \cdots
\end{aligned}
$$

ただし， $V_{p n 0}=Z_{m} I_{0}\left(Z_{m}\right.$ : 架空地線と高圧電線の 相互サージインピーダンス)

最終的に，(付 3) 式を逆ラプラス変換することにより，(17) 式が得られる。

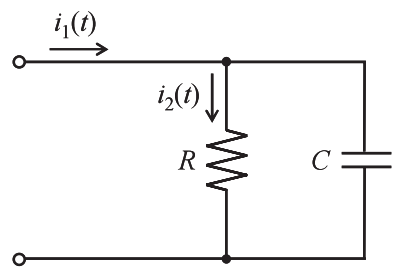

app. Fig. 1. $R C$ parallel circuit. 


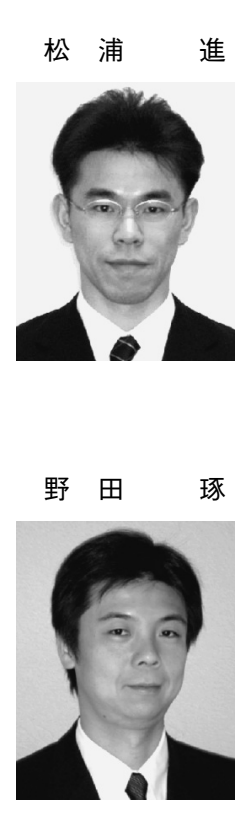

Senior Member。
浅川聡

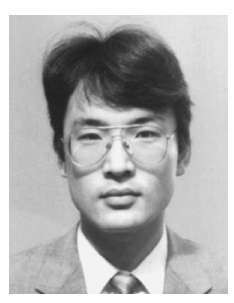

（正員） 1960 年 4 月 19 日生。1985 年 3 月慶応 義塾大学大学院電気工学専攻修士課程修了。同年 4 月 (財) 電力中央研究所入所。現在, 同所電力 技術研究所上席研究員。主として, 配電系統の雷 防護，絶縁協調に関する研究に従事。

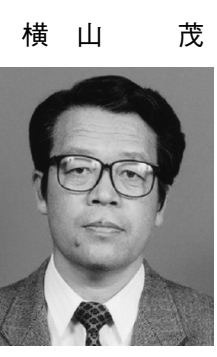

IEEE Fellow。
（上級会員） 1947 年 3 月 5 日生。1969 年 5 月東 京大学工学部電子工学科卒業。同年 6 月 (財) 電力 中央研究所入所。現在, 同所首席研究員。2001 2007 年九州大学客員教授兼任。工学博士。主と して, 電力設備, 建築物, 風力発電設備の雷防護, 絶縁協調に関する研究に従事。2001 年電気学会 副会長。IEC TC81（雷保護）国内委員長。電気学 会評議員。電気学会論文賞, 著作賞, 業績賞受賞。 士 (工学)。電力系統の過渡現象解析手法に関する
研究に従事。2008 年電気学会論文賞受賞。IEEE 